The amounts of mineral components and the sludge loads excreted (parameters expressed in $\mathrm{g} / \mathrm{day} /$ animal) are not significantly different according to the type of feeding and in an animal of comparable weight receiving an equivalent amount of dry matter.

The amount of excreta is highly correlated with the amount of feed ingested, but depends also on the nutrient quality. For instance, ingestion of 23 liters whey would produce an excretion of dry matter equivalent to that obtained with the ingestion of $1 \mathrm{~kg}$ flour.

\title{
Farm wastes in the Lamballe-Matignon region (Côtes-du-Nord)
}

\author{
Ildiko RAKSANYI et Y. ETESSE \\ Chambre régionale d'Agriculture \\ 111, boulevard Maréchal-de-Lattre-de-Tassigny, F 35000 Rennes \\ C.T.G.R.E.F., 17, avenue de Cucillé, F 35000 Rennes
}

The Lamballe-Matignon region has greatly developed its pig and egg production. In 27 towns, 42000 fattening sows and 240000 fattening pigs $(0.9$ fattening sow and 5 fattening pigs per ha agricultural area) and 2700000 poultry were recorded.

Taking into account all the animal species, the excreta may produce per ha agricultural area and per year $160 \mathrm{~N}$ units, $125 \mathrm{P}_{2} \mathrm{O}_{5}$ units and $120 \mathrm{~K}_{2} \mathrm{O}$ units corresponding to a complete soil fertilization. However, there are frequently losses of the fertilizing elements from animal excreta (at collection, storage and manure spreading) and a reduced efficiency on the cultures, especially for nitrogen. Moreover, the available quantities of excreta are variable depending on the towns and the farms and do not always correspond to the culture needs. For instance, 246 farms produce more than $400 \mathrm{~N}$ units/ha, which exceeds their fertilization needs. Others could use more than they produce.

An individual inquiry was made among 133 farmers possessing at least 50 fattening sows or 400 fattening pigs. Most farms have surpluses in $\mathrm{N}, \mathrm{P}_{2} \mathrm{O}_{5}$ and $\mathrm{K}_{2} \mathrm{O}$, which are still increased by the supplies of manure to neighbours and purchases of commercial fertilizers.

Soil analyses were made on 103 parcels, 79 of which had received manure regularly for at least 5 years, not the 24 others. These analyses showed the $\mathrm{P}_{2} \mathrm{O}_{5}$ and $\mathrm{K}_{2} \mathrm{O}$ enrichment of the soils due to animal excreta.

Thus, in this region savings could be made on mineral fertilizers. A better valorization of animal excreta could be obtained from a better knowledge of their fertilizing value, an improvement of pig mature quality, an increase in storage capacities and a development of exchanges between animal producers and neighbour farmers.

\section{Pig manure utilization in a region with pig production units}

\author{
O. LAPIERRE et C. BRETTE \\ Institut National Agronomique Paris-Grignon \\ Centre d'Etudes et de Recherche sur l'Economie et l'Organisation des Productions animales \\ 16, rue Claude-Bernard, F 75231 Paris Cedex 05
}

The results of an inquiry on the pig manure problem made in Brittany during the summer 1980 among 147 farmers have allowed to determine some of the components of this problem. 
Beside the question concerning the manure load per hectare varying from one farm to another, many other elements have to be taken into account to analyse the improvement of the waste utilization policy. According to our investigations, manure is only spread on about one third of the agricultural area and only $14 \mathrm{p} .100$ of the farmers is using it on their whole farmland area. According to these farmers, pig manure spreading is not possible on 7 p. 100 of the agricultural area because of regulations, topography or access to the lots.

Moreover, the choice of the culture and the quantities to spread per type of culture are important factors. For some cereals with straw they do not exceed $50 \mathrm{~m}^{3}$, while for pasture or maize they may exceed $100 \mathrm{~m}$.

Agricultural utilization of manure seems to remain the best solution and the methods used can still be improved. However, the storage capacities represent an important limiting factor for controlling the chronological distribution of manure according to cultures.

\title{
II. - FEEDing
}

\section{Utilization of cereals in simple diets for weaned piglets Influence of the protein level (crude protein and lysine)}

\author{
J. FEKETE *, J. CASTAING **, J-P. BOUARD * \\ et M. LEUILLET * \\ * Institut Technique des Céréales et des Fourrages, \\ 8, avenue du Président-Wilson, F 75116 Paris \\ ** Association Générale des Producteurs de Maïs, \\ 1, place S.-de-Lestapis, F 64000 Pau
}

Six trials were made in the same conditions and in two experimental stations using cereals (wheat, maize, barley) at three protein levels obtained by a soybean meal supplementation $(18,20,22$ p. 100). Furthermore, in order to examine the advantage of using industrial lysine, we tested a fourth diet including 18 p. 100 protein and the same lysine level than that obtained with 22 p. 100 protein feeds.

The incorporation levels of the cereals varied from 53 to 72 p. 100 and that of the soybean meal \& $50 »$ from 19.5 to 38 p. 100 . Piglets were weaned at 26 days of age on an average $(5.9 \mathrm{~kg})$ whereafter the experimental groups were formed taking into account the weight at weaning and the mean litter weight at birth. They were housed in groups of 6 to 7 animals per box in isolated, warmed and ventilated post weaning houses (flat-deck). They were fed for two weeks the first age diet (pellets) already used before weaning, then for 28 or 35 days one of the experimental diets (pellets) ad libitum.

A total of 3096 piglets were used, i.e., 120 to 168 animals per diet.

Simple diets composed of cereals and soybean meal allowed to reach high performance when used between 8-10 and $25-27 \mathrm{~kg}$ in the weaned piglet (feed consumption : 900-1000 g/d, growth : 400 to $600 \mathrm{~g} / \mathrm{d}$ ).

Starting from a protein level of 18 p. 100 it is possible to improve the growth rate and the feed efficiency by increasing the lysine content of the diet either by enhancing the proportion of soybean meal or by adding industrial lysine. The best performance was reached with a diet including 3.5 to $3.8 \mathrm{~g}$ lysine per $1000 \mathrm{Kcal}$ digestible energy. 